\title{
The Effects of European Regulatory Networks on the Bureaucratic Autonomy of National Regulatory Authorities
}

\author{
Ole Andreas Danielsen • Kutsal Yesilkagit
}

(C) Springer Science+Business Media New York 2013

\begin{abstract}
This article discusses the effects of European regulatory networks on the bureaucratic autonomy of national regulators as regards regulatory rule-enforcement and rulemaking. Drawing on institutional theory, the article elaborates scope conditions for networks to yield an effect along this property and assesses these arguments in a study of the formation and institutionalization of the European Competition Network and how it structures relationships between competition authorities and resort ministries in The Netherlands, Sweden and the non-EU member-state Norway. It is argued that by virtue of accumulating and embedding strong norms of independence, the network yields an "autonomizing" effect vis-à-vis participating organizations.
\end{abstract}

Keywords European regulatory networks $\cdot$ National regulatory agencies $\cdot$ Bureaucratic autonomy $\cdot$ Multilevel antitrust enforcement

\section{Introduction}

The rise of European regulatory networks (ERNs) is an important expression of the institutionalization of a European Union (EU) multilevel regulatory administration (Egeberg 2006a; Levi-Faur 2011a). ERNs offer a particularly interesting research site for enduring puzzles within the study of political institutions. There are several reasons why ERNs offer an interesting setting in this regard, the most important one arguably being the fact that ERNs are a new and complex phenomenon in the EU institutional setup. They are not accounted for in the formal treaties, yet they are central for the realization of the substantive goals emanating from these frameworks.

O. A. Danielsen $(\square)$

Department of Administration and Organization Theory, University of Bergen, Bergen, Norway e-mail: ole.danielsen@aorg.uib.no

K. Yesilkagit

School of Governance, Utrecht University, Utrecht, Netherlands

e-mail: a.k.yesilkagit@uu.nl 
ERNs create a bridge between national and supranational administrations in unprecedented ways. In particular, those parts of national administrations possessing regulatory powers have increasingly become linking pins between the national and supranational sphere. A core concern is thus to what extent ERNs change the nature of national administrative systems by altering relationships between regulatory agencies and their principals. Specifically, concerns have been raised that ERNs are weakening the capacity of national politicians to control and steer those parts of their national administrations have become integrated within European networks of regulatory governance (cf. Martens 2008: 40). In this article we aim to examine this claim empirically. The central question this article addresses is therefore: what is the effect of ERNs on the bureaucratic autonomy of national regulatory authorities (NRAs) participating in these networks? The focus on ERNs as the source of the acclaimed causes of weakening (national) democratic control is warranted for at least two reasons.

First, there is a clear normative concern. ERNs are not merely involved in strictly regulatory implementation, i.e. monitoring, interpreting and enforcement of rules to individual cases, but are increasingly important as regards regulatory rule-making as well, seeing as they are engaged in elaborating and amending regulatory frameworks. In particular, the close links that generally exist between ERNs and the "parent" Directorate General (DG) of the European Commission (Commission) implies that the expertise accumulated in ERNs forms an important asset for the Commission in pre-pipeline regulatory policymaking (Coen and Thatcher 2008; cf. also Egeberg 2006b: 198). In other words, the structure and functioning of ERNs may produce effects that increase the regulatory rule-making capacities of national regulatory authorities vis-à-vis the formal rule-making institutions, such as the government or parliament.

The second reason is of a theoretical nature. The literature on ERNs hosts different and not always explicit assumptions on the effects of networks on bureaucratic autonomy. In some frameworks, they are viewed as yielding a more or less independent autonomizing effect (cf. Majone 1997, 2000) while in others they are arenas wherein generic principal-agent relationships play out but with the added complication of introducing a second EU-level principal (Coen and Thatcher 2008; Eberlein and Newman 2008). Others, still, contend that the network effect may very well be negative, as supranational actors and the standards developed within ERNs may constrain national participants (cf. Kelemen 2011; Wilks 2005). A challenge with the literature on ERNs is that there is arguably a gap between "networks" on the one hand and the "network effect" on the other. In brief, there is a need to clarify how and under what conditions networks can yield an effect.

This article makes an effort in that direction by outlining relevant proxies of bureaucratic autonomy and offering an explanatory framework drawing on institutional theory, which highlights some meso-level scope conditions for ERNs to yield an effect. These arguments are assessed empirically vis-à-vis one particular ERN, namely the European Competition Network (ECN), which was formed as part of the 1999-2004 reform of EU antitrust administration. The article examines the institutionalization of the ECN and subsequently compares its impact on the bureaucratic autonomy of national competition authorities (NCAs) in three West European states. In order to balance possible biases resulting from the comparatively strong 
supranational thrust generally seen as permeating this policy-area (Wilks and McGowan 1996), the article compares adaptations towards the ECN in The Netherlands, Sweden and the non-EU member state Norway, whose NCA is not a full member of the network.

The article proceeds as follows. In the next section, the theoretical framework is elaborated, followed by a presentation of the research design. The empirical analysis then proceeds in two sections. First, the origins and institutionalization of the ECN are discussed. Thereafter, a comparative analysis offers insights on the effect of the ECN on the bureaucratic autonomy of NCAs. Drawing on these findings, the final section offers some concluding inferences.

\section{European Regulatory Networks and Bureaucratic Autonomy: A Conceptual Framework}

This section provides a conceptual framework for our study of the estimated effects of ERNs on the bureaucratic autonomy of national regulatory authorities. First we will discuss what the generic concept of bureaucratic autonomy entails within the context of regulatory administration. Then, we will discuss the mechanisms of European regulatory networks through which effects upon the degree of autonomy of regulatory authorities are expected to be triggered.

\section{Bureaucratic Autonomy in Regulatory Administration}

Bureaucratic autonomy is a crucial organizational property in regulatory administration with particular implications for the dynamics of regulation through networks in the EU. That is, the formal and factual autonomy of regulators from extraneous concerns is likely to have an impact on the final products delivered by these entities. ${ }^{1}$ In general, bureaucratic autonomy is a highly variable organizational property. It is likely to vary according to the relative degree of salience characterising a policy-area wherein a bureaucratic agent operates (Jacobsen 1964, Olsen 2009), polity-features such as the number of veto-players and/or degree of political uncertainty, as well as policy-features, such as the degree of complexity and demand for substantive expertise (Gilardi 2002; Elgie and McMenamin 2005).

Regulation comprises several partly overlapping but distinct sub-processes. If regulation is understood as "rule-making, rule-monitoring and rule-enforcement as a bureaucratic enterprise" (Levi-Faur 2011b: 3), what bureaucratic autonomy implies and how much autonomy one can expect to observe is likely to depend on what sub-process of regulation we are studying. When we thus apply the concept of bureaucratic autonomy to the domain of regulatory administration, it should address the two key processes that are central to regulation: rule-enforcement and rulemaking.

\footnotetext{
${ }^{1}$ The distinction between formal and factual autonomy is not trivial. A regulator can score high on formal autonomy without being particularly autonomous in practice, and vice-versa. For an empirical investigation of this puzzle, see Maggetti (2007).
} 
As regards rule-enforcement activities, bureaucratic autonomy firstly relates to the extent to which a regulator can act with relative discretion when putting a legal framework into practice, i.e. during the act of regulation. That is, regulators score high on autonomy if they can apply legal frameworks, define what targets and processes these frameworks are applicable to and sanction non-compliance without external interference (Christensen 2001; Verhoest et al 2010). At the same time, however, regulatory authorities are also involved in regulatory rulemaking. This may involve codifying best practices and establishing guidelines against which subsequent sectoral practices can be modeled and scrutinized. However, it can also take the form of establishing more binding commitments, such as secondary legislation that elaborates and codifies the (often) open norms contained in regulatory frameworks. Despite the mantra of role-purification, which loomed large in regulatory and administrative reforms of recent years (Christensen and Lægreid 2001, 2006), regulators organized at arm's length from political masters are often involved in policymaking as well as enforcement. Their experiences and comparatively higher levels of substantive expertise make them valuable partners for the government and/or the relevant resort ministries in the policymaking process (Bach 2010; Maggetti 2009).

\section{ERNs as Wielders of Bureaucratic Autonomy: Institutional Scope Conditions}

ERNs harbor various assets that deem a study of their potential impact upon the structure and organization of national administrative systems necessary. To begin with, ERNs enable more or less stable patterns of interaction between regulators by embedding decision-making and access structures that channel resources and organize attention (cf. March and Olsen 1976). ERNs may develop into actors in their own right, paralleling and complementing other EU-level institutions as core components in an emerging "single European regulatory space" (cf. Levi-Faur 2011a). The institutionalization of ERNs as actors mirrors one important insight from the study of national bureaucracies, in that their formal institutional design may be a rather weak predictor of their future functioning (Krause and Douglas 2005). Principal-agent theories emphasize the control problems that emerge as agents find their role and interpret, or even reinterpret, their basic missions (Kiewiet and McCubbins 1991). At the same time, any organization ultimately depends on its ability to develop a distinct sense of purpose and a bureau-identity to accompany it in order to craft a distinct "space" in the face of potential environmental threats to its existence (Eisenstadt 1959).

In practice, ERNs may acquire properties akin to that of a distinguishable actor by virtue of their close linkage to policy-directorates within the Commission and/or EUlevel agencies. As Levi-Faur (2011a: 823) argues, these actors "are making considerable investments in institutionalizing them as their agents", thus facilitating the emergence of novel categories of actors such as "networked agencies" and "agencified networks" (cf. ibid: 825-826). Drawing on institutional theory, we will elaborate on the importance of some formal and informal organizational-structural attributes as preconditions for this to take place and sketch some expectations with regards to implications for the bureaucratic autonomy of participating organizations. 
Scholars associated with the "transformation of executive politics in Europe" branch of recent EU scholarship (Egeberg 2004, 2006a; Martens 2010; Trondal 2010) have emphasized the role of inter-institutional interdependencies in the European administrative space. One particularly interesting contribution from this camp has been the argument that structural devolution in national administrations has been a handmaiden for new cooperative frameworks at the transgovernmental level. Egeberg (2006a) argues that "agencification" has created capacities for autonomous action in domestic regulatory administration that have made national regulators ideal partners vis-à-vis the Commission in all stages of the regulatory process.

In a formal sense, cooperative frameworks that re-couple national regulators onto transgovernmental arenas represent formal-structural conditions that are conducive to a general strengthening of national regulators vis-à-vis other domestic actors. In particular, the "incorporation" of ERNs (Eberlein and Newman 2008) designates some organizations as members possessing the relevant expertise for the execution of shared responsibilities, while other organizations are simultaneously excluded. The fact that ERNs specify independent regulatory authorities (IRAs) as members, suggests that the organizational specialization of ERNs at the outset signals an expectation for autonomous action among its incumbents.

The dynamics of de- and re-coupling at the transgovernmental level is likely to be significantly shaped by relative strength of the main supranational actors, i.e. the Commission, vis-à-vis the ERN in question (cf. Barbieri 2006). In some forums, the Commission is merely an observer with few formal means of influencing network activities while in others it has acquired coordinating competences to the extent that it resemble a second principal vis-à-vis national regulators (Coen and Thatcher 2008). This implies that while ERNs may emancipate regulators from domestic constraints, new dependencies may take their place (cf. Martens 2010), thus possibly diminishing the "net" autonomizing effect of ERNs.

When we now turn to the informal attributes of ERNs, we find additional and possibly even more important assets that network incumbents can mobilize vis-à-vis actors in their immediate surroundings. As with all organizations, ERNs may also become infused with distinct norms and values (March and Olsen 2006; Selznick 1957). While such features take time to develop, ERNs are seldom created in an institutional vacuum but are imbued with certain foundational traits that are likely to shape their subsequent developmental paths. ERNs are established to facilitate close cooperation between organizations facing similar concerns and arguably embed strong norms of professionalism and, above all, independence. This does not imply that activities do not have political implications or that interactions are completely de-politicised. However, norms of neutrality and independence establish powerful thresholds against politicking as they frame appropriate behaviour (March and Olsen 2006).

Especially, the expertise-heavy nature of ERNs suggests that activities are likely to have a strong epistemic anchoring and influence may thereby be highly correlated with the ability to produce professionally sound arguments (Haas 1992). Such norms moreover constitute an asset that can be mobilised vis-à-vis external actors. Networks may become "bearers of reputation" and thereby buffer external threats against the autonomy of their incumbents (Majone 1997). Being member of a network gives privileged access to accumulated expertise and may provide additional leeway in 
policymaking by linking organizational preferences to emerging consensuses in the regulatory domain. That is, regulators may "punch above their weight" and gain influence in policymaking processes where their formal role is secondary to that of other actors by virtue of their "organizational reputation" (cf. Carpenter 2001). The other side of this coin is that ERNs may also script appropriate organizational forms and approaches within a given "field" (DiMaggio and Powell 1983) that may be incompatible with the interests and identities of their incumbents.

\section{Research Design}

Ceteris paribus other potential determinants of bureaucratic autonomy that we find in the literature (e.g. national institutional setting, legal basis of authorities, agency leadership, reputation, and so on), we expect that ERNs will have a positive effect on the bureaucratic autonomy - both in terms of regulatory rule enforcement as well as rule-making autonomy - of national regulatory authorities, that become member of an ERN. The formal assets of ERNs that will positively contribute to national regulatory authorities' autonomy vis-à-vis their parent ministry is that membership of an ERN extends the structural and organizational leverage of individual regulatory authorities, incorporating them into a larger and more resourceful aggregate actor. Informally, ERNs are seamless sources of expertise and the hearth of a genuine transnational culture and ideas that differentiate individual regulatory authority from strictly domestic political and administrative cultures and beliefs. In order to take account of other potential explanations within the literature we employ a comparative case design as we compare the effects of ECN on the bureaucratic autonomy of national competition authorities (hereafter: NCAs) in The Netherlands, Sweden and Norway.

The case selection has not been random but is informed by a wish to generate a certain amount of contextual variance, inter alia to balance possible biases arising from analysing developments within a comparatively well-institutionalized supranational policy-domain (i.e. European anti-trust policies), which suggests that it represents a "most likely" case in terms of observing a strong ERN-effect. The comparative logic can be linked to what Frendreis (1983) identifies as a "mixed systems" strategy, which combines elements of a most similar and most different design and therefore allow for cases to vary along both dependent and independent variables (cf. also Christensen and Lægreid 2001).

The cases chosen for analysis are fairly similar with regards to basic polityfeatures. Moreover, they are similar to the extent that they have all adopted equivalent antitrust frameworks that are enforced by semi-independent regulators. On the other hand, different institutional and policy legacies exist and the discretionary leeway enjoyed by the regulators vis-à-vis political executives can be expected to vary accordingly. The countries also vary as regards their formal embedding into the EU competition policy machinery. Including a competition regime wherein the NCA is not a formal member of the ERN being studied, beyond balancing potential biases resulting from the choice of research site, has the added value of increasing contextual variance, thus facilitating a broader assessment of the relative effect of ERNparticipation, compared to other factors. 
In the following section, we first describe the independent variable: the background of the European Competition Network and its formal and informal attributes that are expected to positively influence the bureaucratic autonomy of NCAs. Thereafter we then assess the effects of these attributes of the ECN on the NCAs of the Netherlands, Sweden and Norway. For both parts, we have used both primary and secondary sources of information, i.e. legal and institutional documents, a small number of semi-structured interviews $(\mathrm{N}=15)$ conducted with informants in NCAs and resort ministries in the three countries under study, in addition to a substantial body of secondary literature.

\section{The Autonomy-enhancing Attributes of the European Competition Network}

Antitrust has become an increasingly important area of economic regulation, a development illustrated by the fact the bulk of IRAs in the policy-domain have been created over the past 25 years (cf. Gilardi 2005: 86). At the supranational level, antitrust is a "quasi-constitutional" domain in addition to being a field of economic regulation, intimately linked to the creation of a common market and thus the political project of European integration (Gerber 1998; Maher 2004).

Supranational competences have traditionally loomed large in antitrust administration. The basis for the Commission's strong powers in the antitrust domain emanated from Council Regulation 17/1962, which designated a central role for the supranational regulator in the enforcement of the treaty-based prohibitions against cartels and the abuse of dominant positions. ${ }^{2}$ Crucially, the regulation delegated to the Commission the sole power to grant individual exemptions from the general cartel prohibition ${ }^{3}$ upon prior notification of commercial agreements. The centralized enforcement system was instigated in order to forge regulatory capacities that were largely nascent or non-existent at the domestic level at the time (cf. Gerber 1998: 348-349). As a consequence, it also created formidable administrative challenges for the cartel directorate. Throughout the 1990s, demands for comprehensive reform intensified, not only related to the administrative bottlenecks challenging the centralized notification system (McGowan 2005), but increasingly also targeting the main institutional peculiarity of EU antitrust enforcement, which is that final decisions rests with the College of Commissioners (Karagiannis 2007).

The solution that was opted for was to rely on the regulatory capacities that had gradually emerged at the domestic level. The aforementioned strengthening of national competition policy enforcement from the 1980s onwards had created an institutional infrastructure - a "third force" of regulation (Thatcher 2005) - that could alleviate the increasingly salient capacity problems at the supranational level. Moreover, as many national competition laws had gradually come to be modeled on the EU prohibitions (Kassim and Wright 2010) conditions were increasingly favorable with regards to trusting national authorities with new tasks.

\footnotetext{
${ }^{2}$ These are now to be found in Article 101 and 102 of the Treaty on the Functioning of the European Union (TFEU) respectively, and have remained materially unchanged since the Treaty of Rome (1957).

${ }^{3}$ Cf. the exemption clause in Article 101(3) TFEU.
} 
The "modernization" of EU antitrust culminated in the adoption of Council Regulation 1/2003, abolishing the notification system and decentralizing enforcement responsibilities to national authorities. The sharing of enforcement tasks with NCAs was conditioned upon their participation in a system allowing for information exchanges and central oversight, in order to secure coherence in an enforcement environment potentially characterized by institutional heterogeneity (cf. Cengiz 2010). This tightly coupled system was to be sustained by an ERN, the ECN, which became fully operative as Regulation 1 went into effect on $1^{\text {st }}$ May 2004.

While the ECN is mentioned in Recital 15 of Regulation 1, its practical operation follows from a "joint declaration" between the Commission and the Council (2001) and a subsequent Commission Notice (2004) outlining how the network will function in practice. Thus, the network is a soft law construct and does not possess any legal powers of its own (Wilks 2007: 442). It is essentially a platform designed to realize the objectives set out in the implementing regulation and to facilitate the statutory information exchanges in the enforcement of EU cartel prohibitions. ${ }^{4}$ To this end, several arenas have been established that allow NCAs to discuss issues of common concern, both related to enforcement and policy. ${ }^{5}$ The system as a whole is supported by an obligation towards the acquis as EU antitrust prohibitions are enforced domestically (cf. Art. 3(2) and 16(2)). The ultimate check in this regard is a "claw-back clause" (Art. 11(6)) wherein the Commission can initiate proceedings on its own and thereby relieve the acting $\mathrm{NCA}(\mathrm{s})$ of its competences. ${ }^{6}$

These supervisory arrangements are interesting from the perspective of bureaucratic autonomy. Previous research suggests that they were included to avoid a "renationalization" of policy (Støle 2006: 92) inter alia by exposing common rules to national regimes insufficiently detached from politics (Kassim and Wright 2010: 31, footnote xxiv). ${ }^{7}$ Thus, bureaucratic autonomy emerges as something of a constitutive imperative for this network, ultimately sanctioned by the supranational principal. The primacy of autonomy in decision-making has been noted by scholars observing the reform of EU competition antitrust enforcement as not only pertaining to the capacities of national actors, but indeed the cartel directorate itself.

Karagiannis (2007) makes a case for viewing the creation of the ECN as a deliberate strategy towards emancipating supranational antitrust enforcement via "arena-shifting" (cf. Flinders and Buller 2006). That is, DG COMP acted upon the 'Zeitgeist' of subsidiarity, which provided strong justifications for dispersing

\footnotetext{
${ }^{4}$ I.e. an obligation to apply EU rules in cases having an effect of trade between member-states (Art. 3(1)), to notify the Commission when such investigations are initiated (Art. 11(3)) and to submit draft decisions via the network (Art. 11(4)).

${ }^{5}$ The ECN comprises a Director General meeting, a plenary consisting of heads of ECN units in DG COMP and NCAs, horizontal working groups and sectoral subgroups (European Competition Network 2010: 4). In addition, a virtual structure provides for exchange of information related to enforcement. The advisory committee originally set up under Regulation 17/1962 is not formally part of the ECN, but is still an important forum where member states hear Commission decisions and discuss draft legal texts.

${ }^{6}$ This was a continuation of Art. 9(3) in Regulation 17/1962, but it became more "acute" due to the obligation to apply EU rules domestically. However, the Commission's competences will normally be activated only when agreements affect trade between three or more member-states, following paragraph 14 of the network notice.

${ }^{7}$ This is particularly relevant as the Regulation itself is largely silent on the domestic organization of antitrust, beyond obliging member-states to set up arrangements to secure that the objectives of the regulation are effectively complied with (Art. 35)
} 
responsibilities, in order to alleviate some of its enforcement burdens while at the same time improve its standing vis-à-vis other and less competition-friendly parts of the Commission by introducing new levels of flexibility in enforcement.

“(B)y allowing DG COMP to arbitrage between a Collegial decision or a decision by one or more national competition authorities, Regulation 1 and the ECN put an end to the era of multi-task collegiality" (Karagiannis 2007: 309).

Thus, bureaucratic autonomy emerges as a defining imperative behind the ECN also from the vantage point of the main supranational actor. One implication of this is that it has strong incentives to forge good network relationships. Indeed, recent empirical studies portray intra-network relations as permeated by a strong sense of shared commitment to the network's rationale and activities (Danielsen 2012; Kassim and Wright 2010; Lægreid and Stenby 2010). The cooperative environment has produced results that were not envisioned in Regulation 1, as the network has evolved beyond mere enforcement and is now a ready provider of policy-relevant knowledge vis-à-vis DG COMP in work on legislative questions, for instance related to the drafting of block exemption regulations. Thus, (de-)autonomizing effects of the ECN must be assessed against this background and the variable institutional responses this is likely to trigger at the domestic level.

\section{A Comparative Assessment of the "Network Effect"}

The following comparative discussion assesses how the emergence of the ECN has affected the bureaucratic autonomy of NCAs in the The Netherlands, Sweden and the (formal) outsider Norway, drawing on the conceptualization of bureaucratic autonomy provided earlier. The analysis maps core features of ECN-related adaptations for each of the three cases separately, with our main interest being the relationship between the respective NCAs and their domestic principals (e.g. government and/or parent ministry).

\section{The Netherlands}

The Netherlands adopted the first prohibition based competition law in 1998, marking a decisive step towards harmonizing Dutch antitrust regulation towards the European regime. Antitrust falls under the portfolio of the Ministry of Economic Affairs, Agriculture and Innovation (Ministerie van Economische Zaken, Landbouw en Innovatie) and is enforced by the Dutch Competition Authority (Nederlandse Mededingingsautoriteit, hereafter NMa), created by the 1998 competition act.

In the first years of applying the EU-harmonized competition law, the NMa was not an independent agency but a sub-unit of the ministry, headed by a director general. Antitrust decision-making was therefore subjected to political steering, both via the issuing of guidelines on the interpretation and enforcement of the competition law but also by the fact that the minister retained the right to intervene in politically salient decisions. These prerogatives were deemed necessary given that NMa was a new authority enforcing a novel legal framework and therefore in need of political 
guidance on how to interpret and apply the law (van de Gronden and de Vries 2006). ${ }^{8}$ In 2005, NMa was made an independent administrative authority and the director general post was replaced by a three-person board and headed by a president. NMa staff continued to be employed by the ministry but under the authority of the board in matters pertaining to the enforcement of the law. Political intervention in individual cases was abolished, but the minister retains the possibility to instruct the board on how to take interests other than economic ones into account.

The EU affects NMa via two main channels, via its participation in various EU and ECN-level arenas and, secondly, through the application of EU antitrust rules in the Dutch context. NMa-officials participate broadly across the ECN-structure and the agency cooperates closely with sister-agencies in other EU member-states as well as the Commission as regards the enforcement of EU antitrust rules. ${ }^{9}$ While NMa is fully subjected to the competition acquis and the requirements stipulated in Regulation 1/2003, a second and somewhat more elusive measure of EU-level effects concerns how the agency has made use of its formal discretionary powers to voluntarily adapt to the EU model when developing guidelines and notices concerning the enforcement of antitrust rules. In this regard, previous research indicates that NMa has pushed its own regulatory priorities closer to the EU model by forging competition in domains previously more or less insulated form market forces, including the traditional Dutch "third sector" areas such as social housing corporations and health care delivery (Yesilkagit 2007). Such a regulatory profile is probably closer to the "sound micro economics" approach characterising EU-level developments (cf. Monti 2004) than the neo-corporatist framework Dutch competition policy initially emerged from.

The shift in enforcement profile has arguably made NMa's autonomy more salient. Particularly in purely domestic cases related to for instance the health care sector, social housing, the construction sector and national gas monopoly, decisions of the NMa gain saliency, especially when they question the position of established interests in these areas (e.g. the medical practitioners). Recent developments in the relationship between the agency and the ministry unveil attempts from the political level to curb some of the discretionary powers enjoyed by NMa. Article 13 of the so-called "relations protocol", explicating the relationship between NMa and the resort ministry, was amended in 2010 and now obliges NMa to submit draft executive decisions to the minister for approval (Staatscourant 12076, 29.07.2010).$^{10}$ While this suggests the presence of dynamics that are clearly detrimental to the logic underpinning the ECN, recall that this network is explicitly specialized as to contain such "residual noise" stemming from domestic politics and prevent it from reaching the network. Perhaps as a consequence, then, the changes to the "relations protocol" have not effected the international department within NMa, which is the unit responsible for coordinating ECN-activities. ${ }^{11}$

\footnotetext{
${ }^{8}$ That being said, subsequent ministers never made use of their prerogatives to intervene in agency decisions.

${ }^{9}$ Interviews, NMa 16.09.2010; Ministry of Economic Affairs, Agriculture and Innovation, 06.12.2011, cf. also Yesilkagit (2007).

${ }^{10}$ This was brought on by NMa's decision to impose lower tariffs on the national gas company, which the minister considered to go against the general economic interest of The Netherlands.

${ }^{11}$ Cf. interview, NMa, 16.09.2010.
} 
The EU-related dimension of NMa's work appears to be far less salient than its domestic role, as role-specifications are more or less unambiguous and the relationship between the resort ministry and the agency is characterised by mutual understanding. NMa handles the bulk of ECN-related tasks in its capacity as the competent authority and thereby outside the scope of ministerial control. When legislative matters are discussed within the network, however, this relationship changes. The privileged access enjoyed by NMa to key ECN-forums at an early stage in policymaking processes implies that it will take the lead in legislative matters as well. Yet, legislation is formally the ministry's turf and NMa forwards all relevant information in this regard to the ministry and a common position is developed via consultations prior to discussions at the EU-level, where NMa either participates on its own or alongside officials from the ministry. ${ }^{12}$

While such coordination routinely unveils different priorities, both actors appear aware of their formal roles and the peculiarities characterising the arena within which common positions are eventually forwarded. That is, as the Commission can adopt regulations on its own much is to be gained by downplaying diverging opinions and instead focus attention towards producing a sound argument as a route to influence. This is apparently a main consideration underlying the relationship between the two levels with regards to the ECN. By virtue of its competence and its privileged access to the network, however, NMa arguably has the upper hand vis-à-vis the more multifunctional resort ministry also with regards to legislative discussions.

\section{Sweden}

Competition policy falls under the dossier of the Ministry of Enterprise, Energy and Communications (Näringsdepartementet), administered by the Swedish Competition Authority (Konkurrensverket, hereafter KKV) established in 1992. Having traditionally based antitrust regulation on an abuse-based framework, Swedish legislators copied the entire body of material EU antitrust law in 1993, when preparing membership in the EU/EEA (Jacobsson and Sundström 2006: 92).

The independence of Swedish agencies is linked to the centuries-old principle of political-administrative dualism, which constitutionally prohibits ministerial intervention in agency decision-making when they act on the basis of public law and decides on single cases. It is the government and not the individual minister who is responsible for Swedish agencies (Lægreid and Pedersen 1999). General political guidance thus occurs via budgetary allocations specifying key tasks and objectives to be met by the agency (cf. Jacobsson and Sundström 2006). While this model appears straightforward on paper, its actual implementation has been characterised by variable enthusiasm, in that responsibilities have been moved back and forth between ministries and agencies depending on the salience of the issues at hand and the available expertise in the ministry (Jacobsson 1984; Jacobsson and Sundström 2006). The formal framework as regards antitrust therefore implies that all questions related to enforcement are explicitly out of bounds for the ministry, while in legislative matters the ministry is in the driving seat, as the closest interlocutor vis-à-vis the government.

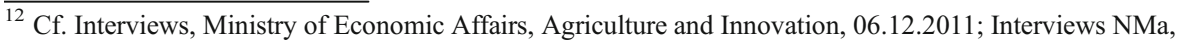
16.09.2010.
} 
Sweden's adaptation towards the EU competition acquis through the adoption of a prohibition-based framework coincided with a general restructuring of the Swedish economy following a period of decline (Gerber 1998: 411). In the early years, a major activity therefore concerned negotiating exemptions from the EU-harmonized rules in areas where national regulatory practices had traditionally been more lenient (cf. Mörth and Jacobsson 1998: 12). KKV has over time become heavily Europeanized however, both in terms of its regulatory profile and its organizational linkage to the ECN. Contacts with sister agencies and the Commission are frequent and KKV is an active participant in all ECN-related activities. ${ }^{13}$ Indeed, Jacobsson and Sundström (2006: 92) comment on KKV's European embedding by noting that the agency "is now equally part of the EU administration as the Swedish, or maybe more" (authors' translation). ${ }^{14}$

European integration has arguably challenged the dualist principle of a strict division of labour between politics and administration as it has spurred a need for inter-sectoral coordination (Jacobsson and Sundström 2006; Jacobsson et al 2004). This is illustrated by Sundström's (2000) analysis of the relationship between KKV and the resort ministry concerning participation in the committees that were set up to advice the Commission on its implementation of antitrust rules in the transport area. In these committees the ministry would send its own officials to participate alongside the agency even though individual cases were discussed, as this was enabled by the specific implementing regulations establishing these committees (cf. Sundström 2000: 47). Following the instigation of Regulation $1 / 2003$ as the general procedural framework these sector-specific committees are gradually disbanded, implying that key decisions will increasingly be made via the general advisory committee. ${ }^{15}$ While this development appears to have been welcomed by Swedish competition officials, it nevertheless curbs the flexibility previously enjoyed by the ministry with regards to representing Sweden in the EU competition advisory committees.

The emergence of the ECN arguably reasserts the strict division of labour implied by the dualist principle as it narrows the scope for organizing transgovernmental relations by designating who the legitimate actors are. The ministry and KKV both emphasise the importance of this principle in defining their relationship with regards to EU-level arenas. ${ }^{16}$ The bulk of ECN-related activities therefore reside with KKV, strictly out of scope for the ministry. As in the Dutch case, the roles shift when it comes to legislation. Here, KKV is bound by national mandates but as the Swedish position is based on information provided by the agency, ${ }^{17}$ it can be seen as exerting considerable influence as it enjoys privileged access to decision-shaping forums within the ECN before issues are eventually put on the agenda as draft legislation. Moreover, the Swedish approach to coordinating national standpoints in the competition area is arguably particularly favourable with regards to the agency exerting such

\footnotetext{
${ }^{13}$ Interview, KKV, 17.12.2010.

${ }^{14}$ In one sense this assertion is valid for all NCAs of EU member states following the enactment of Regulation 1/2003. Strictly speaking, the "allegiance" of an NCA ultimately depends on the ratio of EUrelated enforcement relative to the enforcement of national competition laws.

${ }^{15} \mathrm{Cf}$. also interviews, Ministry of Enterprise, Energy and Communications, 17.12.10.

${ }^{16}$ Interviews, KKV, 17.08.2010, 03.09.2010 and 17.12.2010; Ministry of Enterprise, Energy and Communications, 17.12.2010.

${ }^{17}$ Cf. interviews KKV, 17.12.2010; Ministry of Enterprise, Energy and Communications, 17.12.2010.
} 
influence. As Sundström and Jacobsson (2007: 22) note, KKV has enjoyed broad mandates in EU-level forums as a conscious strategy aimed at increasing its credibility, based on the assumption that credibility is a necessary condition for exerting influence in the expertise-heavy EU competition committees.

\section{Norway}

The first designated Norwegian designated competition law $(1993)^{18}$ did not follow the Swedish route of full-on EU harmonization. With the entry into force of the EEAagreement, two parallel legal frameworks would come to apply, namely a (still largely) abuse-based national competition law and a prohibition-based EEA competition law, which copied the EU antitrust prohibitions (Bue 2000). ${ }^{19}$ It was not until 2004 that an EU-harmonized national competition law was put in place.

Competition policy falls within the dossier of the Ministry of Government Administration, Reform and Church Affairs (Fornyings-, administrasjon- og kirkedepartmentet), whereas the main operative enforcer is the Norwegian competition authority (Konkurransetilsynet, hereafter KT). The autonomy of KT has been a salient topic ever since its establishment in 1994. While semi-independent agencies (direktorater) have a long history as central government organizations in Norway, they are formally embedded in the central government hierarchy. Indeed, the competition authority of Norway is not only KT but also the parent ministry and the King (i.e. cabinet).

Prior to 2004, KT operated in the shadow of ministerial hierarchies in two important respects, as it was both formally under ministerial instruction and decisions taken by KT could be appealed to the ministry. In practice, however, KT enjoyed substantial autonomy as instructing the agency would invoke substantial reputational costs in terms of blurring the organizational distinction between decisions and appeals (cf. also Folmo 2005: 78-79). With the emergence of a centre-right (minority) government in 2001, the commission set up in 2000 to prepare a new competition law was reinstructed to explicitly address the independence of KT (Grønlie and Flo 2009: 346). A new model was proposed, which would remove the right to issue instructions as well as move the appeals to an independent body. This was also in line with this government's general program for reforming Norwegian regulatory agencies (Christensen and Lægreid 2010). In the end, a compromise was reached. The 2004 act removed the possibility of instructing KT in individual decisions, but appeals would still largely remain in the ministry unless KT issues fines, upon which appeals must be taken to the courts. ${ }^{20}$

The EEA-agreement established a parallel institutional structure wherein the EFTA Surveillance Authority (ESA) and the EFTA Court mirror the functions of the

\footnotetext{
${ }_{18}^{18}$ Prior to this law, competition policy was part of a general price regulation framework (Bakke 2005).

19 Article 53 and 54 EEA essentially mirror Article 101 and 102 TFEU.

${ }^{20}$ However, KT can be instructed to take on cases. In addition, section 13 of the competition act allows "the King in Council" (i.e. cabinet) to approve conduct otherwise caught by the general prohibitions as well as reverse cease and desist decisions taken by $\mathrm{KT}$ "in cases involving questions of principle interest or interests of major significance to society". While outside the scope of this article, possibilities for ministerial and political intervention in merger cases are more substantial.
} 
Commission and the European Court of Justice respectively. The decentralization component of Regulation 1/2003 was not fully paralleled as regards the enforcement of the EEA competition rules, despite Norwegian policymakers' expectations to the contrary (Lægreid and Stenby 2010). Instead, the EEA competition rules continue to be principally enforced by ESA and the Commission. If infringements fail to meet the thresholds making either the Commission or ESA competent authority, KT will enforce them as if they were domestic cases under the national competition law. ${ }^{21}$ In practice, however, KT's enforcement of the EEA competition rules will predominantly be related to assisting ESA and the Commission. Participation in the ECN is therefore first and foremost given priority as a channel for influencing rule-making developments at the EU level, seeing as the ECN is not active in the enforcement of the EEA competition rules (cf. Fornyings- administrasjon og kirkedepartementet 2010).

Norwegian antitrust policies have followed a distinct national trajectory, displaying elements of both convergence and divergence vis-à-vis the EU regime. The socalled "bonus prohibition" in the Norwegian competition act, which prohibited bonus programs on domestic flights in order to promote competition among Norwegian airlines, illustrates the latter (Hjelmeng and Sørgard 2011). EU developments nevertheless implicate KT in two important ways. First of all, new EEA-relevant legislation is added to the agreement and thus adopted as national law. Secondly, it has been an explicit goal to harmonize the application of the national law vis-à-vis the EU model. Therefore, general policy developments are also of crucial importance vis-à-vis domestic practices. ${ }^{22}$ For instance, KT's proposal for changes to national leniency policy was directly based on the leniency program developed within the ECN (Fornyings- administrasjon- og kirkedepartementet 2010: 15). Thus, while KT is not a formal member of the ECN, it is nevertheless actively present across the network. In 2007, an amendment to Protocol 23 to the EEA-agreement ${ }^{23}$ regularized KT's access to policy-discussions within the network and furthermore provided for the transfer of all relevant (including confidential) information for these purposes.

One pertinent implication of KT's formal outsider-status is that the formal autonomy enjoyed under the national competition law does not apply to EEA-activities. The general relationship between KT and the ministry follows from a "cooperation notice" (Fornyings-, administrasjons- og kirkedepartementet 2010), which delegates the bulk of operative ECN-activities to KT under nominal ministerial control. As the EEA-rules are principally enforced by the ESA and the Commission, the ministry has organized itself into EEA-cases as a national competition authority and retains the right to instruct $\mathrm{KT}$ in EEA-related matters. ${ }^{24}$ While the ministry can be seen as having a strong formal role vis-à-vis $\mathrm{KT}$, the actual relationship is however more

\footnotetext{
$\overline{{ }^{21}}$ That is, if KT is deemed best placed to act, the restrictions on ministerial instructions will be as under the national competition law. The transfer of cases between EFTA authorities and ESA takes place via a network of EFTA competition authorities, paralleling the ECN in the EFTA pillar (Fornyingsadministrasjon- og kirkedepartementet 2010: 29). It must also be noted that the prerogatives under Section 13 of the national competition law (cf. footnote 20 above) do not apply to these cases (Hjelmeng and Sørgard 2011: 24).

${ }^{22}$ Cf. Interviews, Ministry of Government Administration, Reform and Church Affairs, 20.08.2010; Interview, KT, 03.12.2010 (cf. also Lægreid and Stenby 2010: 7).

${ }^{23}$ This protocol outlines the division of labor between ESA, the Commission and the NCAs of EFTA-states.

${ }^{24}$ Cf. Fornyings- administrasjon- og kirkedepartementet 2010: 8.
} 
similar to the cases discussed earlier in that the ministry is more predominantly engaged in legislative work within the ECN, and under these circumstances KT is formally acting on centrally coordinated national mandates. ${ }^{25}$

The perils of associated membership seem to impact on how formal frameworks play out in practice. While the ministry retains the right to request information and instruct KT, the organizational specialization of the ECN clearly discourages ministerial activism by creating thresholds for what sort of information non-core actors can hope to receive. That is, KT's obligations to submit information to the ministry must be balanced against its commitments to the network and in particular the signals received from the network principal. ${ }^{26}$ As mandates are ultimately based on information regarding network activities (Lægreid and Stenby 2010), what the formal structure prescribes in terms of authority and influence is therefore quite possibly an imprecise predictor of how these properties play out in practice.

\section{Discussion and Conclusion}

The central rationale of this article has been to sketch a meso-level explanation in order to analyze the dynamics and significance of ERNs and we have illustrated the relevance of this account by highlighting their effects on core organizational properties of their incumbents. This article has focused on bureaucratic autonomy and argued in favor of employing a broader perspective on autonomy that is more sensitive to the breadth of regulatory sub-activities ERNs are involved in, and focused in particular on meso-level conditions under which ERNs may exert an effect on the bureaucratic autonomy of participating organizations.

Our empirical observations illustrate the relevance of such a meso-level account. The article has demonstrated how the ECN emerged as a response to increasingly vocal demands for comprehensive changes, wherein the credibility of the supranational regulator itself was at stake. The ECN was thus as a "disciplined" (Wilks 2007) solution to these capacity problems, but it is a solution wherein the "network manager" has more in common with the participating national actors than its supranational peers. The ECN increasingly carries an institutional weight of its own, despite its predominantly soft law foundation and (formally) centralized organizational structure, with significant implications the participating national actors. Our findings suggest that across all three national competition regimes, the NCAs have become strengthened vis-à-vis domestic resort ministries as a function of the institutionalization of the ECN. Clearly, the analyses demonstrate the importance of separating between formal and factual expressions of bureaucratic autonomy, as "autonomizing" effects also materialize with regards to policymaking processes.

The institutionalist framework adopted in this article implies that we have given preference to meso-level variables, and in this regard we have also emphasized the role of contextual variables embedding regulatory authorities at the domestic level. In

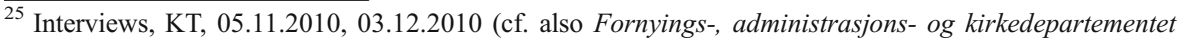
2010: 21).

${ }^{26}$ Cf. Interviews, Ministry of Government Administration, Reform and Church Affairs, 20.08.2010; interview KT 03.12.2010.
} 
the final analysis, bureaucratic autonomy is both forged and possibly constrained as regulators are embedded across different "orders" prescribing different and not always easily reconcilable decision-making premises (cf. Olsen 2007).

The article has shed light on what happens when elements of national and emerging transnational administrative systems cross path. The emergence of transnational entities such as the ECN may, first of all, reinforce elements of the established institutional order. This is illustrated by the observation that the dualist principle in Swedish administrative governance has arguably been reasserted as regards KKV's ECN-related work. What we learned from the Dutch case is that the ECN may consolidate the bureaucratic autonomy of the regulator when the $\mathrm{NMa}$ is acting upon cases with a strong European or international dimension, as was illustrated by reference to the recent domestic attempts to curb the regulator's bureaucratic autonomy. However, in cases where a European dimension is as good as absent, the autonomy of the NMa becomes a function of other determinants, such as its leadership's skills, public opinion and its formal autonomy. Finally, the analysis also demonstrates how the ECN may at times also buffer the effects of formal domestic constraints. The Norwegian case illustrates this final point, as ECN-related activities are both subjected to excessive formal coordination and at the same time significantly framed by the modus operandi of this network, which effectively discourages activism on behalf of non-core actors, such as resort ministries and thereby frame access-structures in favor of the competition authority.

The theoretical ambition of this article is essentially generic as it has emphasized the significance of inter- and intra-bureaucratic dynamics in shaping transnational regulatory spaces. As such, the article has sought to contribute to the literature on the political significance and, by extension, democratic implications of bureaucratic organization (see Farazmand (2010) and Peters (2010) for recent contributions to this debate). The article has made a case for viewing ERNs as actors and emphasized some institutional scope conditions under which they are likely to yield an effect vis-à-vis their incumbents. When this line of reasoning has value for the study of multilevel antitrust governance, with its institutional peculiarities, there are no $a$ priori reasons to assume that this approach will not be of relevance vis-à-vis other domains. Rather, this article has suggested a reinterpretation of the dynamics of change in transnational regulatory administration, in particular emphasizing the meso-level embedding of the politics of structural choice and the role and significance of regulatory bureaucracies at the transnational level. The merits of this approach should therefore deserve further attention from students of other regulatory domains as well.

\section{References}

Bach, T. (2010). Policy and management autonomy of federal agencies in Germany. In P. Lægreid \& K. Verhoest (Eds.), Governance of public sector organizations. Proliferation, autonomy and performance. Palgrave MacMillan: Basingstoke.

Bakke, E. (2005). Fra regulering til konkurranse ("From regulation to competition"). Horisont, 1(2005), $10-23$. 
Barbieri, D. (2006). Transnational networks meet national hierarchies: the cases of the Italian competition and environment administrations. In M. Egeberg (Ed.), Multilevel union administration: the transformation of executive politics in Europe. Basingstoke: Palgrave MacMillan.

Bue, L.A. (2000): Nasjonale konkurranseregimer under press. En komparativ studie av europeiseringen av det norske og svenske konkurranseregimet ("National competition regimes under pressure: a comparative study of the Europeanization of the Norwegian and Swedish competition regime"). Rapport 0007. Bergen: Stein Rokkan Center for Social Science.

Carpenter, D. (2001). The forging of bureaucratic autonomy. Reputations, networks and policy innovation in executive agencies 1862-1928. Princeton: Princeton University Press.

Cengiz, F. (2010). Multilevel governance in competition policy: the European Competition Network. European Law Review, 35, 660-677.

Christensen, J. G. (2001). Bureaucratic autonomy as a political asset. In B. G. Peters \& J. Pierre (Eds.), Politicians, bureaucrats and administrative reform. London: Routledge.

Christensen, T. and P. Lægreid (2001, eds.): New public management. The transformation of ideas and practice.

Christensen, T., \& Lægreid, P. (2006). Autonomy and regulation. Coping with agencies in the modern state. Cheltenham: Edward Elgar.

Christensen, T., \& Lægreid, P. (2010). Increasing complexity in public organizations - the challenges of combining NPM and post-NPM features. In P. Lægreid \& K. Verhoest (Eds.), Governance of public sector organizations. Proliferation, autonomy and performance. Basingstoke: Palgrave MacMillan.

Coen, D., \& Thatcher, M. (2008). Network governance and multilevel delegation: European networks of regulatory agencies. Journal of Public Policy, 28, 49-71.

Council Regulation (EEC) 17/1962: Regulation No. 17: First Regulation implementing Articles 85 and 86 of the Treaty. O.J. P 013, 21.02.1962

Council Regulation (EC) 1/2003 of December 162002 on the implementation of the rules on competition laid down in Articles 81 and 82 of the Treaty. OJ L 1, 04.01.2003.

Danielsen, O. A. (2012). Structuring transnational regulatory space: contending images of the design and implementation of European regulatory networks. Paper presented at the annual department seminar of the Department of Administration and Organization Theory, 5-6 December 2012.

DiMaggio, P., \& Powell, W. (1983). The iron-cage revisited: institutional isomorphism and collective rationality in organizational fields. Am Sociol Rev, 48, 147-160.

Eberlein, B., \& Newman, A. (2008). Escaping the international governance dilemma? Incorporated transgovernmental networks in the European Union. Governance, 21, 25-52.

Egeberg, M. (2004). An organisational approach to European integration: outline of a complementary perspective. European Journal of Political Research, 43, 199-219.

Egeberg, M. (2006a). Multilevel union administration: the transformation of executive politics in Europe. Basingstoke: Palgrave MacMillan.

Egeberg, M. (2006b). Conclusion. In M. Egeberg (Ed.), Multilevel union administration: the transformation of executive politics in Europe. Palgrave MacMillan: Basingstoke.

Eisenstadt, S. (1959). Bureaucracy, bureaucratization and de-bureaucratization. Adm Sci Q, 4(3), 302-320.

Elgie, R., \& McMenamin, I. (2005). Credible commitment, political uncertainty, or policy complexity? Explaining the discretion granted to independent administrative authorities in France. British Journal of Political Science, 35, 531-548.

European Commission (2004): Commission Notice on cooperation within the Network of Competition Authorities. OJ C 101, 27.04.2004.

European Commission and the Council (2001): Joint statement of the Council and the Commission on the functioning of the network of competition authorities. 15435/702.

European Competition Network (2010): "A look inside the ECN: its members and its work". ECN Brief Special Issue, December 2010. Available at: http://ec.europa.eu/competition/ecn/brief/05_2010/brief_ special.pdf (last visited 10.12.2012).

Farazmand, A. (2010). Bureaucracy and democracy: a theoretical analysis. Public Organization Review, 10, 245-258.

Flinders, M., \& Buller, J. (2006). Depoliticization, democracy and arena-shifting. In T. Christensen \& P. Lægreid (Eds.), Autonomy and regulation. Coping with agencies in the modern state. Cheltenham: Edward Elgar Publishing.

Folmo, J. (2005). Konkurransetilsynet: en studie av endringsprosesser og reguleringsatferd. («The competition agency: a study of organizational change and regulatory behavior»). Department of Political Science: Oslo.

Fornyings- administrasjon og kirkedepartementet (2010): EØS-avtalens konkurranseregler. Samarbeidet mellom FAD og Konkurransetilsynet $i$ EØS-saker ('The competition rules of the EEA-agreement: the 
cooperation between the Ministry of Government Administration and Reform and the Competition Authority in EEA-matters"). Public version. January 2010. Oslo: Fornyings-, administrasjon og kirkedepartementet.

Frendreis, J. P. (1983). Explanation of variation and detection of covariation: the purpose and the logic of comparative analysis. Comparative Political Studies, 16, 255-272.

Gerber, D. (1998). Law and competition in Twentieth century Europe: protecting Prometheus. Oxford: Oxford University Press.

Gilardi, F. (2002). Policy credibility and delegation to independent regulatory agencies: a comparative empirical analysis. Journal of European Public Policy, 9, 873-893.

Gilardi, F. (2005). The institutional foundations of regulatory capitalism: the diffusion of regulatory agencies in Western Europe. The ANNALS of the American Academy of Political and Social Science, 598, 84-101.

Grønlie, T., \& Flo, Y. (2009). Sentraladministrasjonens historie etter 1945 ("The history of the Norwegian central government after 1945”). Bergen: Fagbokforlaget.

Haas, P. M. (1992). Introduction: epistemic communities and international policy coordination. Int Organ, $46,1-35$.

Hjelmeng, E. and L. Sørgard (2011): Konkurransepolitiske virkninger av EØS-avtalen. ('Effects of the EEA-agreement on competition policy"). Report no. 15. Oslo: Europautredningen

Jacobsen, K. D. (1964). Teknisk hjelp og politisk struktur ('Technical help and political structure”). Oslo: Universitetsforlaget.

Jacobsson, B. (1984). Hur styrs förvaltningen? ("How is the administration governed?"). Lund: Studentlitteratur.

Jacobsson, B., \& Sundström, G. (2006). Från hemvävd til invävd. Europeiseringen av svensk förvaltning och politik ("From homebound to embedded. The Europeanization of Swedish administration and politics"). Stockholm: Liber Forlag.

Jacobsson, B., Lægreid, P., \& Pedersen, O. K. (2004). Europeanization and transnational states. Comparing Nordic central governments. London: Routledge.

Karagiannis, Y. (2007). Preference heterogeneity and equilibrium institutions: the case of European competition policy. Florence: European University Institute.

Kassim, H. and K. Wright (2010): The European Competition Network: a regulatory network with a difference. Paper presented at the ECPR Regulation Conference, Dublin, June 2010.

Kelemen, R. D. (2011). Eurolegalism. The transformation of law and regulation in the European Union. Cambridge, MA: Harvard University Press.

Kiewiet, D. R., \& McCubbins, M. D. (1991). The logic of delegation. Congressional parties and the appropriations process. Chicago: University of Chicago Press.

Krause, G. A., \& Douglas, J. W. (2005). Institutional design versus reputational explanations of agency performance: evidence from U.S. macroeconomic and fiscal projections. Journal of Public Administration Research and Theory, 15, 281-306.

Lægreid, P., \& Pedersen, O. K. (1999). Fra oppbygning til ombygning $i$ staten. Organisasjonsendringer $i$ de nordiske landene.("From construction to reconstruction of the state: organizational changes in the Nordic countries"). Copenhagen: Jurist- og Økonomforbundets Forlag.

Lægreid, P. and O. Stenby (2010): Europeanization and transnational networks. A study of the Norwegian competition authority. JPRG Paper No. 25, September 2010. Jerusalem: Jerusalem Forum for Regulation and Governance.

Levi-Faur, D. (2011a). Regulatory networks and regulatory agencification: towards a single European regulatory space”. Journal of European Public Policy, 18(6), 810-829.

Levi-Faur, D. (2011b): The Odyssey of the regulatory state. Episode one: the rescue of the welfare state. JPRG Paper No. 39, November 2011. Jerusalem: Jerusalem Forum for Regulation and Governance.

Maggetti, M. (2007). De facto independence after delegation: a fuzzy-set analysis. Regulation \& Governance, 1, 271-294.

Maggetti, M. (2009). The role of independent regulatory agencies in policymaking: a comparative analysis. Journal of European Public Policy, 16, 445-465.

Maher, I. (2004). Networking competition authorities in the European Union: diversity and change. In C. D. Ehlerman \& I. Atanasiu (Eds.), European Competition Law Annual 2002: Constructing the EU network of competition authorities. Oxford/Portland Oregon: Hart Publishing.

Majone, G. (1997). The new European agencies: regulation by information. Journal of European Public Policy, 4, 262-275.

Majone, G. (2000). The credibility crisis of Community regulation. Journal of Common Market Studies, 38, 273-302. 
March, J. G., \& Olsen, J. P. (1976). Ambiguity and choice in organizations. Bergen: Universitetsforlaget. March, J. G., \& Olsen, J. P. (2006). The logic of appropriateness. In M. Moran, M. Rein, \& R. E. Goodin (Eds.), The Oxford Handbook of Public Policy. Oxford: Oxford University Press.

Martens, M. (2008). Run-away bureaucracy? Exploring the role of Nordic regulatory agencies in the European Union. Scandinavian Political Studies, 31(1), 27-43.

Martens, M. (2010): Organized administrative integration. Report 10/2. Oslo: ARENA Centre for European Studies.

McGowan, L. (2005): Europeanization unleashed and rebounding. Assessing the modernization of EU cartel policy. Journal of Common Market Studies

Monti, M. (2004). A reformed competition policy: achievements and challenges for the future. SPEECH/ 04/477. Brussels: DG COMP.

Mörth, U., \& Jacobsson, K. (1998). Paradoxes of Europeanization. Swedish cases. Report 1998: 2. Stockholm: SCORE.

Olsen, J. P. (2007). Europe in search of political order. Oxford: Oxford University Press.

Olsen, J. P. (2009). Democratic government, institutional autonomy and the dynamics of change. West European Politics, 32, 439-465.

Peters, B. G. (2010). Bureaucracy and democracy. Public Organization Review, 10, 209-222.

Selznick, P. (1957). Leadership in administration. A sociological interpretation. Berkeley: University of California Press.

Staatscourant (Official gazette): no. 12076, 29 July 2010.

Støle, Ø. (2006). Towards a multilevel union administration? The decentralisation of EU competition policy. In M. Egeberg (Ed.), Multilevel union administration: the transformation of executive politics in Europe. Palgrave MacMillan: Basingstoke.

Sundström, G. (2000). Fallstudie av det svenska EU-arbetet på konkurrensområdet ("Case study of the Swedish EU-work in the competition domain"). Stockholm: Statskontoret.

Sundström, G., \& Jacobsson, B. (2007). The embedded state. From government to governance: the case of Sweden. Report 2007: 3. Stockholm: SCORE.

Thatcher, M. (2005). The third force? Independent regulatory agencies and elected politicians in Europe. Governance, 18, 347-373.

Trondal, J. (2010). An emergent European executive order. Oxford: Oxford University Press.

Van de Gronden, J. W., \& de Vries, S. A. (2006). Independent competition authorities in the EU. Utrecht Law Review, 2, 32-66.

Verhoest, K., Roness, P. G., Verschuere, B., Rubecksen, K., \& MacCarthaigh, M. (2010). Autonomy and control of state agencies. Comparing states and agencies. Basingstoke: Palgrave MacMillan.

Wilks, S. (2005). Agency escape: decentralization or dominance of the European Commission in the modernisation of competition policy? Governance, 18, 431-452.

Wilks, S. (2007). Agencies, networks, discourses and the trajectory of European competition enforcement. European Competition Journal, 3(2), 415-442.

Wilks, S., \& McGowan, L. (1996). Competition policy in the European Union. Creating a federal agency. In B. Doern \& S. Wilks (Eds.), Comparative competition policy. National institutions in a global market. Cambridge: Cambridge University Press.

Yesilkagit, K. (2007) Whose regulators? Competing perspectives on bureaucratic autonomy - the case of the Dutch Competition Authority. Paper presented at the ECPR General Conference, Pisa, 68 September 2007.

Ole Andreas Danielsen is PhD-student at the Department of Administration and Organization Theory, University of Bergen.

Kutsal Yesilkagit is Associate Professor at Utrecht School of Governance, Utrecht University. 